\title{
Supplier-Contractor Partnering Impact on Construction Performance: A Study on Malaysian Construction Industry
}

\author{
N. A. Mirawati, S. N. Othman, and M. I. Risyawati
}

\begin{abstract}
The construction sector plays an important role in the national economy through strengthening and enabling other sectors. Construction provides basic amenities and infrastructures that support social development. Despite its important contribution, the industry is still saddled with serious problems such as poor quality, low productivity, poor image, economic volatility, bureaucratic delays, and cost overruns. With an eye to overcoming these problems, this paper proposed a study on supplier-contractor partnering and its impact on construction performance.
\end{abstract}

Index Terms-Construction management, performance, partnering and supplier - contractor relationships.

\section{INTRODUCTION}

The construction industry in Malaysia is among the major economic sectors that contribute significantly towards the economic growth of the country. Over the last 20 years, the industry has consistently contributed approximately 3-5\% towards the national Gross Domestic Product [1]. Construction plays a central role in driving economic growth and socio-economic development due to both its growth-initiating and growth-dependent nature [2].

Malaysia is currently in the process of industrialization, of which the construction industry plays a crucial part. This is due to the fact that it provides the economic and social infrastructure for industrial production and reproduction. Basic amenities such as roads, airports, railways, ports, hospitals, schools, housings etc., are needed to improve social living standards and quality of life, which in turn, promote better utilization of physical and human resources[3]. Realizing the importance of the construction industry, the government has allocated a large amount of the budget under the Tenth Malaysia Plan (2011-2015), to enhance the growth of the construction sector and thus transform Malaysia into a developed country. In line with the aspiration to become a developed nation by the year 2020 , the provision of world-class infrastructure will be developed. Fifty-two high impact projects worth RM 67.2 billion will be implemented towards achieving the national mission. The prominent infrastructural facilities include building roads and railway networks that will lead to key ports and airports [4].

Nevertheless, the Malaysian construction industry as a whole is underachieving. There has been disenchantment with the industry's ability to deliver projects on schedule,

Manuscript received September 7, 2013; revised November 10, 2013.

The authors are with the School of Technology Management and Logistics at Universiti Utara Malaysia, 06010, Sintok, Kedah, Malaysia. (e-mail: adlin.mirawati@gmail.com, snorezam@gmail.com, risyawati@uum.edu.my). within budget, and of acceptable quality [5], [6]. It is salient for public projects to be completed on time, as clients, users, stakeholders, and the general public's usually looks at project success from the macro view [7]. Studies reveal that $90 \%$ of Majlis Amanah Rakyat (MARA) projects are experiencing construction delays which decelerate the implementation of MARA strategic planning [8], [9]. The Malaysia External Trade Development Corporation (MATRADE) project also faced nine years of delay with a 70\% cost overrun due to the abandonment of the project by the original contractor and the resulting appointment of another. Meanwhile, the second Penang Bridge, which is currently under construction, has been delayed for more than 12 months due to additional technical challenges that were not considered in the early stages. Additionally, the second bridge is facing quality problems; recently the exit ramp connector of the second bridge of Penang collapsed and killed four workers [10]. This incident will clearly affect the expected project execution date of September 2013.

Similarly, the Sultan Mizan Zainal Abidin Stadium's roof collapsed in 2011. The RM292 million stadium roofs had first collapsed in 2009 due to a damaged steel structure causing injuries to five workers [11]. The damages loss was estimated to be between RM15 million and RM25 million with major causes identified as faulty design and low quality materials. Some other predicaments included the crack at the pier heads of the Kuala Lumpur Middle Ring Road 2 flyover, and Puchong Jaya flyover, and the collapsed of the Kuala Dipang suspension bridge. More recently, the collapsed of the lightning arrestor from the top of Menara Umno in Jalan Macalister which crushed seven vehicles [12].

Furthermore, the private sector is also suffering from project overruns. According to an April 2013 National Housing Department report, 191 projects were considered "sick" while 30 projects were delayed. The delayed projects were defined as having time overruns between $10 \%$ to $30 \%$ compared to the actual schedule while "sick" projects were either facing time overruns of more than $30 \%$ from the actual schedule or elapsed purchase agreement [13]. From the statistics, it is obvious that the housing industry is facing serious issues.

With the aim of overcoming the mentioned problems, previous researchers have investigated the relationships between the client, contractor and consultant [14]-[17]. And yet, the results of these researches have not been prolific enough in relieving these problems. What has not been looked at was the fact that subcontractors are carrying out $85 \%$ of the work [18]. Thus, it is crucial to investigate supplier-contractor relationships in order to assure the success of Malaysia's infrastructure goals. 


\section{LITERATURE REVIEW}

\section{A. Construction Performance}

Traditionally, a construction project is considered successful when it is completed on time, within budget, and of acceptable quality regardless of the complexity, size, and the environment within which it is constructed [19]-[22]. However, construction performance is subject to many variables and unpredictable factors. The performance of parties, resource availability, environmental conditions, and contractual relations contribute to construction performance [23].

Based on the previous literature, most problems arose from contractors' inefficient site management, poor site coordination, improper planning, financial difficulties and problems with subcontractors [6], [23]-[30]. This can be explained by the fragmented nature of the construction project which consists of numerous parties which in turn makes the project difficult to coordinate [31], [32]. Each of the parties is involved at different phases of a construction project and differs in terms of work activities, technologies and experience [33]. Such complex relationships may adversely affect a project's performance or lead to disputes and confrontational relations between the parties if they are not managed properly [34]-[37].

Moreover, the construction industry is a very competitive high-risk business. Many problems, such as poor cooperation, lack of trust and ineffective communication may result in adversarial relationships between contracting parties [38]. Besides, the shift of responsibilities from the client to main contractor through integrated contract has increased the dependence of main contractor on subcontractors. Kadir [39] argued that coordination problems between main contractors and subcontractors is a major hindrance to work progress. For instance, late issuance of revised construction drawings to subcontractors can cause rework due to construction errors. In order to perform effectively, contractors and their subcontractors must understand how their actions affect each other. This is because the parties in the construction project are interdependent and failure of any of the parties will seriously affect project quality and execution [34]. Latham [40] and Egan [41] reports suggested that construction performance can be improved through greater teamwork not only at the site and organizational level but also with clients and suppliers; which can be implemented through partnering. Besides, there is a consensus among researchers that supplier-contractor relationships may directly affect construction performance [42], [43].

There has been scant research undertaken to understand supplier and contractor relationships in Malaysia. Previous studies in Malaysia focused on issues pertaining to the causes of delay, procurement, construction methods, payment and defects [3], [6], [44]-[48]; while empirical evidence in supplier-contractor partnering impacts on performance is still lacking. This is supported by Bemelmans et al., [49] who argued that most of the literature focuses on the aspects of partnering conditions, characteristics, barriers and subcontracting issues. Supplier-contractor research in the construction industry is still under-researched.

Critically, past studies include the main contractor and subcontractors together under the same entity [50]. It is a fallacy to assume that the main contractor and subcontractors are equal in nature. The main contractor who has financial capability will normally have more than one project at any time and is primarily concerned with the administrative and tendering works. In contrast, $89.5 \%$ of subcontractors are from small to medium-sized enterprises, which have unstable financial backgrounds and business management practices [28]. Thus, it is important to study supplier and main contractor separately and a study on supplier-contractor partnering within the construction industry is deemed necessary.

\section{B. Supplier-Contractor Partnering}

Normally, the winning contractor will always divide the project into multiple subcontracts; this is because the main contractor does not possess certain skills and expertise. Generally, $85 \%$ of construction tasks are executed by the subcontractors, thus subcontractor performance will determine the success or failure of any project [18], [51]. Sambasivan and Soon [6] argued that a high degree of subcontracting often leads to a high risk of time overruns and causes inefficiencies to the local construction industry.

General contractor-subcontractor transactions involve a significant amount of uncertainty and the reliance on subcontractors places much stress on the subcontractor-main contractor relationship. $75 \%$ of total costs are derived from purchased materials and services [52]. Thus, the greatest potential cost savings lie within subcontractors emphasizing the importance of managing suppliers. The main contractors also believed that in order to perform productively, they have to work closely with subcontractors by developing closer working relationships [53]. Unfortunately, most of relationships between main contractors and subcontractors are often strained and adversarial [54].

In order to overcome these problems, "partnering" is recommended to reduce the adversarialism between the parties by encouraging better integration and cooperation [55]. Numerous definitions of partnering have been derived from previous studies. Few scholars use partnering interchangeably with collaboration [56]. Nonetheless, the most referred definition was developed by the Construction Industry Institute (CII) which defines partnering as

A long-term commitment between two or more organizations for the purposes of achieving specific business objectives by maximizing the effectiveness of each participant resources. This requires changing traditional relationships to a shared culture without regard to organizational boundaries. The relationship is based on trust, dedication to common goals, and an understanding of each other's individual expectations and values (CII, 1991).

Previous studies on client, consultant and contractors relationships; indicates that partnering has a positive impact on project performance, not only with regard to time, cost and quality; but also improvement in profit margins and reduced litigations. Weston and Gibson [57] revealed that partnering project performs better than those projects managed in an adversarial manner. Moreover, partnering enhance better risk management within both upstream and downstream relationships which in turn help to improve user 
satisfaction [15], [58]. Client-main contractor relationship is upstream while main contractor-subcontractor relationships is downstream [59].

Akintoye and Main [42]; Saad, Jones and James [60] indicate that project underperformance is caused by the main contractor tendency to focus on dyadic relationships between themselves and clients; neglecting the importance of subcontractors and suppliers. This is due to the financial funding and workload provided by the client. Saad and Jones (1999, as cited in Akintoye [61]) highlights that downstream is the weaker link and needs to be improved if the full potential of supply chain management is to be realized. Furthermore, changes in client demands from just price to criteria like innovations, sustainability and speed require the main contractor to build a closer relationship with the subcontractors, thus emphasizing the importance and significance of managing suppliers [49].

Therefore, this study intends to investigate supplier-contractor partnering impacts on construction performance. It attempts to fill in a gap in the knowledge by providing answer to whether poor performance among contractors and suppliers can significantly be reduced by adopting partnering approaches.

\section{Partnering Measurements}

Based on previous literature, partnering can be described by the elements of mutual trust, communication, long-term perspectives, problem solving, mutual objective and equity [39], [43], [53], [55], [56], [62]. These attributes are chosen to measure supplier-contractor partnering for this study.

\section{1) Mutual trust}

Previous scholars have identified that partnering is a trust-based relationship [39], [42]. Trust serves to combine the resources and knowledge of the partners and intended to eliminate adversarial relationships[55]. Each party should believe that the other parties are reliable in executing the work and fulfil their obligations [39].

\section{2) Communication}

The construction industry are described as highly fragmented, interdependent and dependent on information sharing [63]. Timely accurate communication between the parties is crucial to achieve project success.

\section{3) Long-term perspectives}

Long-term commitment can be regarded as the willingness of the involved parties to integrate continuously to unanticipated problems [64].

\section{4) Problem solving}

Construction projects involve numerous parties that possess different skills, goals and expectations. Hence, problems and conflicts are unavoidable during project execution[33]. Therefore, good problem solving is an important criteria to identify good partnering between the parties [59].

\section{5) Mutual objectives}

Mutual objectives ensure that the interests of every party such as completing the project on schedule, within budget, increasing cost-effectiveness, sharing best work practices will be best served [33].

\section{6) Equity}

The interests of all stakeholders should be considered when developing goals and risks and rewards should be fairly shared. There must be a commitment to satisfy each stakeholder requirement to ensure project satisfaction and success [65].

\section{Measuring Construction Performance}

Project performance will be measured in terms of time, cost and quality. Although there are many ways to measure performance; time, cost and quality are often used to measure a project's success [66]. Atkinson [67] referred to these criteria as the "iron triangle".

\section{1) Cost}

Cost is the degree to which the general conditions promote the completion of a project within the estimated budget [68]. Cost is not only confined to the tender sum, it is the overall cost that a project incurs from inception to completion, which includes any costs arise from variations, modification during construction period and the cost arising from the legal claims, such as litigation and arbitration [66].

\section{2) Time}

Time is the most crucial element in measuring project success and it is referred to the duration for completing the project. It is scheduled to enable the building to be used by a date determined by the client's future plans [69].

\section{3) Quality}

Quality is defined as meeting the customer's expectations, or compliance with customer's specification in terms of appearance, performances, and reliability of the project for a given price range [70]. Bubshait et al., (1994) describes quality as meeting of the project's established requirements in term of materials and workmanship [68].

\section{E. Research Framework}

The research framework was developed from past studies and is presented schematically in Fig. 1. The independent variable for this study is supplier-contractor partnering and will be measured by mutual trust, communication, long-term perspectives, problem solving, mutual objectives and equity. Meanwhile, the construction performance will be measured by cost, quality and time.

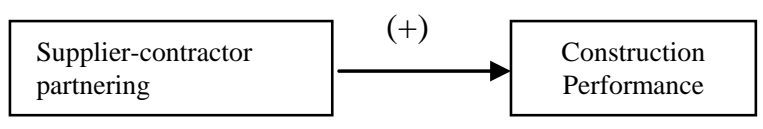

Fig. 1. Research framework.

The hypothesis is that supplier-contractor partnering will have a significantly positive effect towards the construction performance.

\section{F. Research Methodology}

This research will be based on random sampling survey by using questionnaire. The questionnaire consists of three sections related to project and respondent information, partnering, and construction performance. It will be distributed among contractors from grade G6 and G7 in Peninsular Malaysia. The target population for this study is 
5,828 contractors and based on Krejcie and Morgan table [71], the appropriate sample size is 361 contractors. The main contractors are chosen because of their experiences in dealing with subcontractors and suppliers.

\section{CONCLUSION}

For many years, the Malaysian construction industry has faced underperformance. The impacts have been significant with a tendency to decelerate the country's transformation into a developed nation by year 2020. Thus, to overcome these issues, this paper proposes a study to investigate supplier-contractor partnering impacts on construction performance.

\section{REFERENCES}

[1] Department of statistics Malaysia, "Quarterly construction statistics," 2013.

[2] A. S. Ali, Z. M. Don, A. Alias, S. N. Kamaruzzaman, and M. Pitt, "The performance of construction partnering projects in Malaysia," International Journal of Physical Sciences, vol. 5, no. 4, pp. 327-333, 2010.

[3] A. R. B. Ibrahim, M. H. Roy, Z. Ahmed, and G. Imtiaz, "An investigation of the status of the Malaysian construction industry," Benchmarking: An International Journal, vol. 17, no. 2, pp. 294-308, 2010.

[4] The Star, "PM tables RM230bil 10th Malaysia Plan," The Star Online, 10 Jun 2010

[5] A. S. Ali and S. N. Kamaruzzaman, "Cost performance for building construction projects in Klang Valley," Journal of Building Performance, vol. 1, no. 1, pp. 110-118, 2010.

[6] M. Sambasivan and Y. W. Soon, "Causes and effects of delays in Malaysian construction industry," International Journal of Project Management, vol. 25, no. 5, pp. 517-526, Jul. 2007.

[7] C. Lim and M. Z. Mohamed, "Criteria of project success: An exploratory re-examination," International Journal of Project Management, vol. 17, no. 4, pp. 243-248, Aug. 1999.

[8] M. R. Abdullah, I. A. Rahman, and A. A. A. Azis, "Causes of delay in MARA management procurement construction projects," Journal of Surveying, Construction and Property, vol. 1, no. 1, pp. 123-138, 2010.

[9] A. H. Memon, I. A. Rahman, M. R. Abdullah, A. Asmi, and A. Azis, "Assessing the effects of construction delays on MARA large projects," in Proc. International Conference on Advanced Science, Engineering and Information Technology, 2011, pp. 624-629.

[10] New Straits Times, "Second Penang bridge collapse: Rescue teams scour for survivors," New Straits Times, 18 Jun 2013.

[11] The Star, "Five hurt after stadium roof under re-construction collapses," The Star Online, 17 Apr 2013.

[12] Bernama, "Collapsed structure a lightning arrestor, says MCMC," The Star Online, 14 Jun 2013.

[13] National Housing Department, "Statistik projek-projek perumahan swasta bermasalah (Kategori sakit \& lewat) sehingga 30 April 2013," 2013.

[14] A. M. Anvuur and M. M. Kumaraswamy, "Conceptual model of partnering and alliancing," Journal of Construction Engineering Management, vol. 133, pp. 225-234, 2007.

[15] M. Bresnen and N. Marshall, "Building partnerships: Case studies of client - contractor collaboration in the UK construction industry," Construction Management and Economics, vol. 18, pp. 819-832, 2000.

[16] L. L. Anderson and B. Polkinghorn, "Managing conflict in construction megaprojects: Leadership and third-party principles," Conflict Resolution Quarterly, vol. 26, no. 2, pp. 167-198, 2008.

[17] M. Bresnen and N. Marshall, "The engineering or evolution of co-operation?" A Tale of Two Partnering Projects, vol. 20, pp. 497-505, 2002.

[18] J. Hinze and A. Tracey, "The contractor-subcontractor relationship: The subcontractor's view," Journal of Construction Engineering and Management, vol. 120, no. 2, pp. 274-287, 1994.

[19] A. P. C. Chan, D. Scott, and E. W. M. Lam, "Framework of success criteria for design/build projects," Journal of Management in Engineering, no. 18, pp. 120-128, 2002.
[20] A. A. Othman, J. V. Torrance, and M. A. Hamid, "Factors influencing the construction time of civil engineering projects in Malaysia," Engineering, Construction and Architectural Management, vol. 13, no. 5, pp. 481-501, 2006.

[21] A. Enshassi, J. A. Najjar, and M. Kumaraswamy, "Delays and cost overruns in the construction projects in the Gaza Strip," Journal of Financial Management of Property and Construction, vol. 14, no. 2, pp. 126-151, 2009.

[22] I. A. Rahman, A. H. Memon, and A. T. A. Karim, "Relationship between factors of construction resources affecting project cost," Modern Applied Science, vol. 7, no. 1, pp. 67-75, Dec. 2013.

[23] S. A. Assaf and S. A. Hejji, "Causes of delay in large construction projects," International Journal of Project Management, vol. 24, no. 4, pp. 349-357, May 2006.

[24] G. Sweis, R. Sweis, A. A. Hammad, and A. Shboul, "Delays in construction projects: The case of Jordan," International Journal of Project Management, vol. 26, no. 6, pp. 665-674, Aug. 2008.

[25] H. Doloi, A. Sawhney, K. C. Iyer, and S. Rentala, "Analysing factors affecting delays in Indian construction projects," International Journal of Project Management, vol. 30, no. 4, pp. 479-489, May 2012.

[26] T. Pourrostam and A. Ismail, "Causes and effects of delay in Iranian construction projects," International Journal of Engineering and Technology, vol. 4, no. 5, pp. 5-8, 2012.

[27] A. Kazaz, S. Ulubeyli, and N. A. Tuncbilekli, "Causes of delays in construction projects in Turkey," Journal of Civil Engineering and Management, vol. 18, no. 3, pp. 426-435, Jun. 2012.

[28] H. A. Rahman, R. Takim, and W. S. Min, "Financial-related causes contributing to project delays," Journal of Retail and Leisure Property, vol. 8, no. 3, pp. 225-238, Aug. 2009.

[29] M. R. Abdullah, I. A. Rahman, and A. A. A. Azis, "Delay in large MARA construction projects based on project management consultant perspective," in Proc. Malaysian Technical Universities Conference on Engineering and Technology, 2009, pp. 9-13.

[30] L. L. Hoai, Y. D. Lee, and J. Y. Lee, "Delay and cost overruns in Vietnam large construction projects: A comparison with other selected countries," KSCE Journal of Civil Engineering, vol. 12, no. 6, pp. 367-377, Nov. 2008.

[31] A. Cox and P. Ireland, "Managing construction supply chains: The common sense approach," Engineering, Construction and Architectural Management, vol. 9, no. 5/6, pp. 409-418, 2002.

[32] S. Naoum, "An overview into the concept of partnering," vol. 21, pp. 71-76, 2003.

[33] W. T. Chen and T.-T. Chen, "Critical success factors for construction partnering in Taiwan," International Journal of Project Management, vol. 25, no. 5, pp. 475-484, Jul. 2007.

[34] G. K. Kanji and A. Wong, "Quality culture in the construction industry," Total Quality Management, vol. 9, no. 4-5, pp. 133-140, 1998.

[35] E. W. L. Cheng and H. Li, "Development of a conceptual model of construction partnering," Engineering, Construction and Architectural Management, vol. 8, no. 4, pp. 292-303, 2001.

[36] E. Larson, "Project Partnering: Results of study of 280 construction projects," Journal of Management Engineering, vol. 11, no. 2, pp. 30-35, 1995.

[37] H. Lee, J. Seo, M. Park, H. Ryu, and S. Kwon, "Transaction-cost-based selection of aappropriate general contractor-subcontractor relationship type," Journal of Construction Engineering and Management, vol. 135, pp. 1232-1240, 2009.

[38] A. P. C. Chan, D. W. M. Chan, Y. H. Chiang, B. S. Tang, E. H. W. Chan, and K. S. K. Ho, "Exploring critical success factors for partnering in construction projects," Journal of Construction Engineering and Management, pp. 188-198, 2004.

[39] M. R. A. Kadir, W. P. Lee, M. S. Jaafar, S. M. Sapuan, and A. A. A. Ali, "Factors affecting construction labour productivity for Malaysian residential projects," Structural Survey, vol. 23, no. 1, pp. 42-54, 2005.

[40] S. M. Latham, Constructing the Team, London, 1994.

[41] S. J. Egan, Rethinking Construction, 1998.

[42] A. Akintoye and J. Main, "Collaborative relationships in construction: the UK contractors' perception," Engineering, Construction and Architectural Management, vol. 14, no. 6, pp. 597-617, 2007.

[43] C. Black, A. Akintoye, and E. Fitzgerald, "An analysis of success factors and benefits of partnering in construction," International Journal of Project Management, vol. 18, pp. 423-434, 2000.

[44] A. R. A. Aziz and P. S. J. Kassim, "Objectives, success and failure factors of housing public-private partnerships in Malaysia," Habitat International, vol. 35, pp. 150-157, Jan. 2011. 
[45] W. S. Hui, R. Othman, N. H. Omar, R. A. Rahman, and N. H. Haron, "Procurement issues in Malaysia," International Journal of Public Sector Management, vol. 24, no. 6, pp. 567-593, 2011.

[46] M. Jaafar and A. R. Nuruddin, "The development of public and private construction procurement systems in the Malaysian construction industry," Journal of Design and Built Environment, vol. 11, 2012.

[47] M. A. Razak and M. Jaafar, "An assessment on faulty public hospital design in Malaysia," Journal Design and Built, vol. 5, 2012

[48] M. Jaafar and N. M. Radzi, "Level of satisfaction and issues with procurement systems used in the Malaysian public sector," Australasian Journal of Construction Economics and Building, vol. 13, no. 1, pp. 50-65, 2013.

[49] J. Bemelmans, H. Voordijk, and B. Vos, "Supplier-contractor collaboration in the construction industry: A taxonomic approach to the literature of the 2000-2009 decade," Engineering, Construction and Architectural Management, vol. 19, no. 4, pp. 342-368, 2012.

[50] K. C. Iyer and K. N. Jha, "Factors affecting cost performance: Evidence from Indian construction projects," International Journal of Project Management, vol. 23, no. 4, pp. 283-295, May 2005.

[51] J. Mbachu, "Conceptual framework for the assessment of subcontractors' eligibility and performance in the construction industry," Construction Management and Economics, vol. 26, no. 5, pp 471-484, May 2008.

[52] P. A. Koushki, K. A. Rashid, and N. Kartam, "Delays and cost increases in the construction of private residential projects in Kuwait," Construction Management and Economics, vol. 23, no. 3, pp. 285-294, Mar. 2005.

[53] J. Matthews, A. Tyler, and A. Thorpe, "Pre-construction project partnering: Developing the process," Engineering, Construction and Architectural Management, vol. 3, no. 1/2, pp. 117-131, 1996.

[54] A. R. J. Dainty, S. J. Millett, and G. H. Briscoe, "New perspectives on construction supply chain integration," Supply Chain Management: An International Journal, vol. 6, no. 4, pp. 163-173, 2001.

[55] L. Cook and D. E. Hancher, "Partnering: Contracting for the future," Journal of Management in Engineering, vol. 6, no. 4, pp. 431-446, 1990.

[56] H. Li, E. W. L. Cheng, and P. E. D. Love, "Partnering research in construction," Engineering, Construction and Architectural Management, vol. 7, no. 1, pp. 76-92, 2000.

[57] D. C. Weston and G. E. Gibson, "Partnering-Project Performance in U.S. Army Corps of Engineers," Journal of Management Engineering, vol. 9, no. 4, pp. 410-425, 1992.

[58] G. D. Wood and R. C. T. Ellis, "Main contractor experiences of partnering relationships on UK construction projects," Construction Management and Economics, vol. 23, no. 3, pp. 317-325, Mar. 2005.

[59] X. Meng, "The effect of relationship management on project performance in construction," International Journal of Project Management, vol. 30, no. 2, pp. 188-198, Feb. 2012.

[60] M. Saad, M. Jones, and P. James, "A review of the progress towards the adoption of supply chain management (SCM) relationships in construction," European Journal of Purchasing \& Supply Management, vol. 8, no. 3, pp. 173-183, Sep. 2002.

[61] A. Akintoye, G. McIntosh, and E. Fitzgerald, "A survey of supply chain collaboration and management in the UK construction industry,"
European Journal of Purchasing \& Supply Management, vol. 6, no. 3-4, pp. 159-168, Dec. 2000.

[62] E. W. L. Cheng and H. Li, "Construction partnering process and associated critical success factors: Quantitative investigation," Journal of Management in Engineering, pp. 194-202, October 2002.

[63] P. A. Bowen and P. J. Edwards, "Interpersonal communication in cost planning during the building design phase," Construction Management and Economics, vol. 14, no. 5, pp. 395-404, 1996.

[64] M. Bresnen and N. Marshall, "Motivation, commitment and the use of incentives in partnerships and alliances," pp. 587-598, 2000.

[65] S. T. Ng, T. M. Rose, M. Mak, and S. Eng, "Problematic issues associated with project partnering - the contractor perspective," International Journal of Project Management, vol. 20, pp. 437-449, 2002.

[66] A. P. C. Chan and A. P. L. Chan, "Key performance indicators for measuring construction success," Benchmarking: An International Journal, vol. 11, no. 2, pp. 203-221, 2004.

[67] R. Atkinson, "Project management: cost, time and quality, two best guesses and a phenomenon, its time to accept other success criteria," International Journal of Project Management, vol. 17, no. 6, pp 337-342, Dec. 1999.

[68] A. A. Bubshait and S. A. Almohawis, "Contract procurement: Evaluating the general conditions of a construction contract," International Journal of Project Management, vol. 12, no. 3, pp. 133-136, 1994.

[69] Z. Hatush and M. Skitmore, "Evaluating contractor prequalification data: Selection criteria and project success factors," Construction Management and Economics, vol. 15, no. 2, pp. 129-147, 1997.

[70] K. N. Jha and K. C. Iyer, "Critical Factors Affecting Quality Performance in Construction Projects," Total Quality Management, vol. 17, no. 9, pp. 1155-1170, 2006

[71] R. V. Krejcie and D. W. Morgan, "Determining sample size for research," Educational and Psychological Measurement, vol. 30, pp. 607-610, 1970.

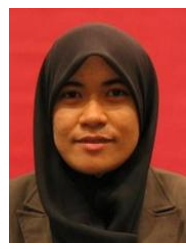

Nur Adlin Mirawati is currently doing her master degree in technology management by full research. She received her Bachelor in Technology Management from University Utara Malaysia in 2011.

Siti Norezam Othman is an associate professor in the School of Technology Management and Logistics at Universiti Utara Malaysia. Her research interests are technology transfer and product development.

Risyawati Mohamed Ismail is a lecturer in the School of Technology Management and Logistics at Universiti Utara Malaysia. Received her M.B.A from Universiti Utara Malaysia in 2004 and holds a degree in Microbiology from Universiti Sains Malaysia. Her research interests are lean manufacturing and manufacturing strategies. 